\title{
Magnetic Resonance-Guided High-Intensity Focused Ultrasound (MR-HIFU): Overview of Emerging Applications (Part 2)
}

\section{Der Magnetresonanz-gesteuerte hochintensive fokussierte Ultraschall (MR-HIFU): Überblick über neue Anwendungsgebiete (Teil 2)}

Authors

Florian Siedek, Sin Yuin Yeo, Edwin Heijman, Olga Grinstein, Grischa Bratke, Carola Heneweer, Michael Puesken, Thorsten Persigehl, David Maintz, Holger Grüll

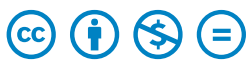

Affiliation

Institute of Diagnostic and Interventional Radiology,

University-Hospital of Cologne, Germany

Key words

HIFU, interventional procedures, ablation procedures, prostate, breast, abdomen

received 23.05.2018

accepted 24.11.2018

Bibliography

DOI https://doi.org/10.1055/a-0817-5686

Published online: 10.1.2019

Fortschr Röntgenstr 2019; 191: 531-539

(c) Georg Thieme Verlag KG, Stuttgart · New York

ISSN 1438-9029

Correspondence

Prof. Holger Grüll

Radiology, University Hospital of Cologne,

Kerpener Str. 62, 50937 Cologne, Germany

Tel.: ++ 49/221/47882035

holger.gruell@uk-koeln.de

\section{ZUSAMMENFASSUNG}

Hintergrund Der hochintensive fokussierte Ultraschall (HIFU) ermöglicht das nichtinvasive Erhitzen tief gelegener Gewebsschichten. Die MRT-geführte HIFU-Behandlung (MRHIFU) erlaubt die präzise Therapieplanung sowie MR-basierte Temperaturmessungen im Gewebe, wodurch eine genau definierte thermale Dosis appliziert werden kann.

Methoden Publikationen zu MR-HIFU wurden studiert und in diesem Review zusammengefasst. Hierbei wurde die Literatur auf onkologische Applikationen beschränkt.

Ergebnisse Neueste Studien zur MR-HIFU-Therapie des Prostatakarzinoms bestätigten diese als sichere und patientenfreundliche Methode. Zur MR-HIFU-Therapie des Mammakarzinoms und Tumorerkrankungen der abdominellen Organe wurden bisher Machbarkeitsstudien publiziert.
Zusammenfassung MR-HIFU wird derzeitig für die Thermoablation von malignem Gewebe bei verschiedenen Krebsentitäten untersucht. Die sowohl transrektale als auch transurethrale Ablation des Prostatakarzinoms mittels MR-HIFU erwies sich als patientenfreundlich und sichere Alternative mit geringen Komplikationen im Vergleich zu anderen lokalen Therapieoptionen.

\section{Kernaussagen:}

- Die MR-Steuerung ermöglicht Therapieplanung auf MRBildern, nichtinvasive Temperaturmessungen in Echtzeit sowie postinterventionelle Therapiekontrolle.

- Spezielle HIFU-Transducer und Technologien zur Therapie vom z. B. Prostata- und Mammakarzinom oder malignen Erkrankungen der Abdomen-Organe sind vorhanden.

\section{ABSTRACT}

Background High-intensity focused ultrasound (HIFU) allows noninvasive heating of deep-seated tissues. Guidance under magnetic resonance imaging (MR-HIFU) offers spatial targeting based on anatomical MR images as well as MR-based nearreal-time temperature maps. Temperature feedback allows delivery of a well-defined thermal dose enabling new applications such as the ablation of malignant tissue.

Methods Peer-reviewed publications on MR-HIFU were studied and are summarized in this review. Literature was restricted to applications in oncology.

Results Several MR-HIFU-based applications for the treatment of malignant diseases are currently part of clinical trials or translational research. Recent trials regarding the treatment of prostate cancer with MR-HIFU have already shown this to be a safe and patient-friendly method. For the treatment of breast cancer and malignancies within abdominal organs, MR-HIFU has been applied so far only in proof of concept studies.

Conclusion MR-HIFU is currently being investigated for the ablative treatment of malignant tissue in a variety of oncological applications. For example, the transrectal as well as transurethral ablation of prostate cancer using MR-HIFU was shown to be a patient-friendly, safe alternative to other local treatment options with low side effects. 
Key points:

- MR guidance offers high soft tissue contrast for treatment planning, near-real-time temperature monitoring, and post-interventional therapy evaluation.

- Special HIFU transducers and technological solutions are available for the treatment of e. g. prostate cancer, breast cancer or abdominal malignancies.

\section{Citation Format}

- Siedek F, Yeo SY, Heijman E et al. MR-Guided High-Intensity Focused Ultrasound (MR-HIFU): Overview of Emerging Applications (Part 2). Fortschr Röntgenstr 2019; 191: 531539

\section{Introduction}

High-intensity focused ultrasound (HIFU) can be used to noninvasively ablate deep-seated tissue. The procedure is usually carried out under image guidance using either diagnostic ultrasound (US-HIFU) or magnetic resonance imaging (MR-HIFU) to provide spatial targeting and to monitor the ablation process in real time. Both US-HIFU and MR-HIFU are clinically used and approved for various applications with several emerging applications currently being evaluated in clinical trials. In the first part of this review (Magnetic Resonance-Guided High-Intensity Focused Ultrasound (MR-HIFU): Technical Background and Overview of Current Clinical Applications (Part 1)), we recently discussed the technical details of HIFU including the two image guidance approaches and subsequently reviewed the main clinical applications of MR-guided HIFU applications. In short, MR guidance provides anatomical images with high soft-tissue contrast and offers the additional advantage of near real-time temperature mapping which allows delivery of well-defined thermal doses while protecting heat-sensitive structures. In this second part, we will review several new and emerging applications, however again limited to MR-HIFU. Since important US-guided HIFU studies exist for some applications, we will refer interested readers to relevant reviews.

\section{Prostate}

In the last decades, prostate-specific antigen (PSA) screening has improved the detection of prostate cancer, particularly of localized low- and intermediate-risk prostate cancer (PCa) [1]. Beside the increased incidence of PCa, the precise mortality benefit of early detection is still unclear and controversially discussed. This observation could be partly explained by the detection of primarily low- and intermediate-risk prostate carcinomas and the low disease-specific ten-year mortality or elderly men with a life expectancy of less than ten years [2, 3]. The Prostate Cancer Intervention Versus Observation Trial (PIVOT) found that prostatectomy for PSA-diagnosed low-risk PCa might provide only limited benefit [4], and the Scandinavian Prostate Cancer Group Study Number Four (SPCG-4) found that prostatectomy is only beneficial for patients under 65 years of age with clinically diagnosed PCa [5]. Thus, in addition to radical prostatectomy and externalbeam radiation therapy (EBRT), conservative strategies, such as active surveillance and watchful waiting, are gaining increasing importance for personalized clinical management for low- and intermediate-risk cancer patients. Even if conservative management is indicated, some patients (up to 5-10\%) still prefer a more radical approach [6], such as a radical prostatectomy, despite its associated complication rates with remaining incontinence in up to $31 \%$ [7] and erectile dysfunction in up to $50 \%$ [8]. Hence, less invasive interventional therapies, such as HIFU, are gaining importance for whole-gland or focal treatment of prostate cancer. For example, the 2016 EAU-ESTROSIOG guidelines state that even though focal therapy for localized PCa remains experimental due to the lack of convincing long-term results, salvage HIFU is a recommended thermal ablation option for radiation-recurrent PCa [9]. In addition, despite multifocal occurrence of PCa [10], up to one third of patients with localized prostate cancer have unilateral disease that may be suitable for focal treatment, e. g. targeted ablation, hemiablation or zonal ablation. Recently, the French Urological Association evaluated US-HIFU hemiablation for the primary treatment of low- and intermediate-risk PCa in the prospective multi-institutional IDEAL study [11]. The results revealed a $95 \%$ absence of clinically significant cancer associated with a low morbidity after 1 year, and a radical treatment-free survival rate of $89 \%$ after 2 years. After 1 year, continence and erectile functions were preserved in $97 \%$ and $78 \%$, respectively, and severe adverse events (grade $\geq 3$ ) were reported in only $13 \%$.

So far, the most common HIFU approaches in prostate cancer treatment employ transrectal ultrasound-guided (US-) HIFU transducers (Ablatherm ${ }^{\circledR}$, Sonablate ${ }^{\circledR}$, FocalOne ${ }^{\circledR}$ ), with their efficacy being well reviewed by Chaussy CG and Thüroff S [12]. The main drawback of these US-HIFU systems is the missing visualization of the target lesion and the missing real-time temperature control during ablation. In contrast, MRI allows visualization of the target lesion and provides real-time temperature mapping to deliver well-defined and well-controlled thermal doses during HIFU therapy. Thus, MR-HIFU seems to be the preferred imaging modality for guiding HIFU intervention compared to US-HIFU [13-15]. The current clinically available MR-HIFU transducers are the ExAblate ${ }^{\circledR}$ system (Insightec, Haifa, Israel) with a transrectal probe and the TULSA-PRO ${ }^{\circledR}$ (Profound Medical, Mississauga, Canada) with a transurethral probe. Both systems received CE label and are currently under clinical evaluation or collecting posttreatment data in multi-national clinical trials for localized (up to $50 \%$ of prostate volume) ablation (ExAblate ${ }^{\circledR}$ ) and whole-gland ablation (TULSA-PRO ${ }^{\circledR}$ ) in patients with localized, organ-confined prostate cancer (TACT trial inclusion closed). 


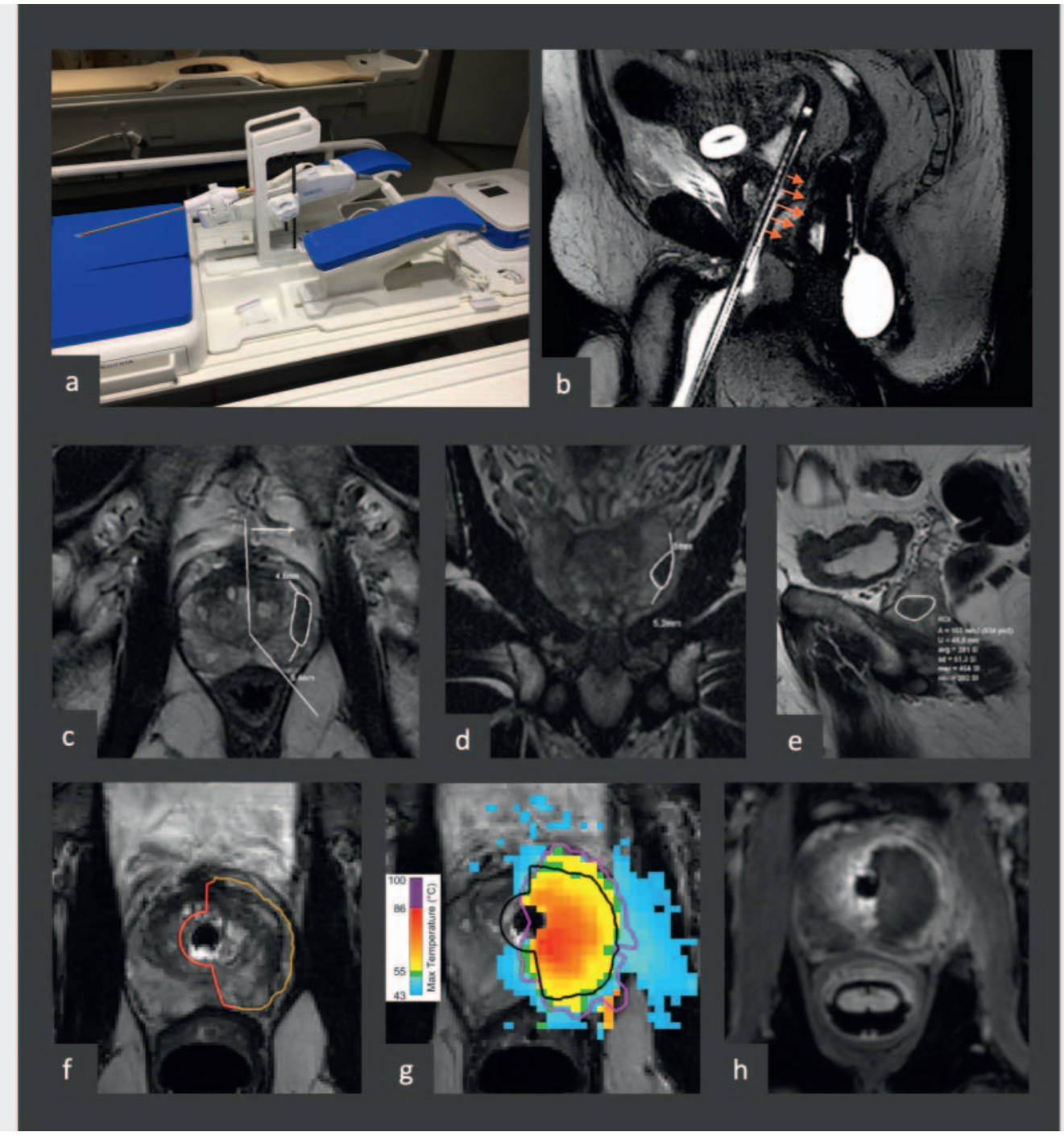

- Fig. 1 Overview of prostate cancer ablation (PIRADS 4, Gleason 7a) via a transurethral approach (TULSA-PRO, Profound Medical, Mississauga, Canada). a Transurethral catheter with HIFU transducer elements at the tip mounted on a motor stage allowing rotation of the catheter. $\mathbf{b}$ Catheter is inserted into the urethra with the transducer elements placed inside the prostate. For ablation, the tip can be rotated to reach all targeted areas. c-e Planning of the therapy using transverse, coronal and sagittal high-resolution MR images of the prostate in which the tumor was marked. f Delineation of the target tissue is performed manually. $\mathbf{g}$ MR thermometry map acquired during therapy showing maximum temperature reached. Automatic adjustments of rotation speed, power output, and frequency enable precise heating and therefore accurate ablation of the previously marked tissue. $\mathbf{h}$ Post-therapy acquired CE MRI showing the non-perfused volume (NPV).

- Abb. 1 Überblick über die Ablation eines Prostatakarzinoms (PI-RADS 4, Gleason 7a) mittels transurethralem Vorgehen (TULSA-PRO, Profound Medical, Mississauga, Canada). a Ein transurethraler Katheter mit HIFU-Transducer-Elementen an der Spitze wird von einem Motor angetrieben, der die Rotation des Katheters erlaubt. b Der Katheter wird so in die Urethra eingebracht, dass die HIFU-Elemente innerhalb der Prostata liegen. Für die Ablation kann die Katheter-Spitze rotieren, um alle zu therapierenden Areale zu erreichen. c-e Therapieplanung anhand hochaufgelöster transversaler, koronarer und sagittaler MR-Bilder der Prostata, in denen der Tumor markiert wurde. $\mathrm{f}$ Die Bestimmung des zu abladierenden Zielgewebes erfolgt manuell. g MR-Thermometrie-Karte, die während der Untersuchung aufgezeichnet wird und die maximal erreichte Temperatur darstellt. Die automatisierte Anpassung der Rotationsgeschwindigkeit, der Leistungsabgabe und der verwendeten Frequenz ermöglicht die präzise Erhitzung und folglich akkurate Ablation des zuvor markierten Gewebes. h Nach Therapie akquirierte KM-unterstützte Sequenz, die das nicht perfundierte Volumen (NPV) zeigt.

In a prospective single-center phase I clinical trial using the MRI-guided ExAblate ${ }^{\circledR}$ transrectal HIFU probe, 8 men with 10 lesions with low- and intermediate-risk prostate cancer (Gleason $6-7)$ were treated and followed for 6 months [16]. All patients were discharged within 4 hours after treatment. Only one patient developed a urinary tract infection and prostatitis, the other patients did not show any complications in the follow-up examinations. In one patient, treatment failed with significant residual disease and the need for prostatectomy and 4 out of 10 lesions revealed residual malignant tissue in the biopsy 6 months after treatment that could not be recognized on MRI. Although this study was limited by a small sample size and short follow-up, it still showed the transrectal MR-HIFU approach to be safe with low complication rates and an acceptable oncologic 

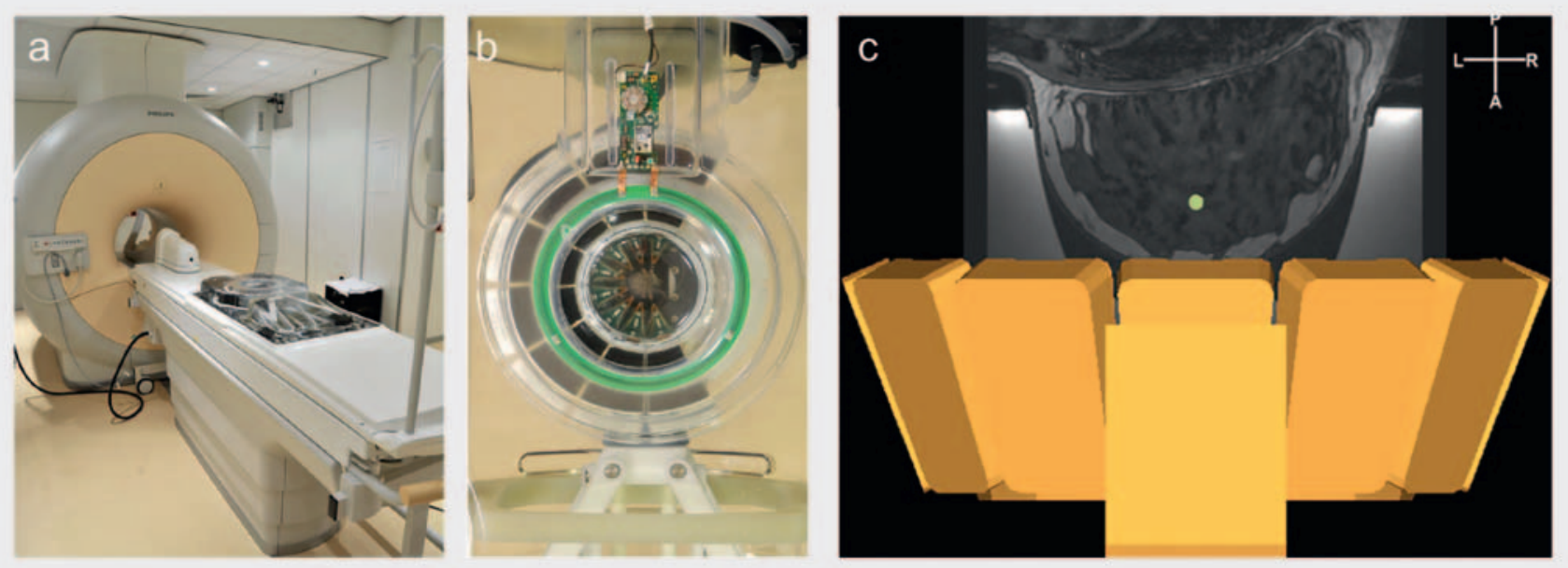

- Fig. 2 a, b Dedicated MR-HIFU breast platform (prototype, Profound Medical, Mississauga, Canada) allowing sparing of the thoracic wall during treatment. c Schematic view of laterally mounted ultrasound transducers with the green spot indicating the sonication cell within the middle of the breast. Source: Merckel LG, Bartels LW, Köhler M, van den Bongard HJ, Deckers R, Mali WP, Binkert CA, Moonen CT, Gilhuijs KG, van den Bosch MA. MR-guided high-intensity focused ultrasound ablation of breast cancer with a dedicated breast platform. Cardiovasc Intervent Radiol 2013; 36: 292 - 301 [rerif].

- Abb. 2 a, b Dedizierte MR-HIFU-Brustplattform (prototype, Profound Medical, Mississauga, Canada) mit der Möglichkeit zur Schonung der Thoraxwand während der Therapie. c Schematische Darstellung der lateral angebrachten Ultraschall-Transducer, wobei der grüne Punkt eine Sonikations-Zelle in der Mitte der Brust darstellt. Quelle: Merckel LG, Bartels LW, Köhler M et al. MR-guided high-intensity focused ultrasound ablation of breast cancer with a dedicated breast platform. Cardiovasc Intervent Radiol 2013; 36: 292 - 301 [rerif].
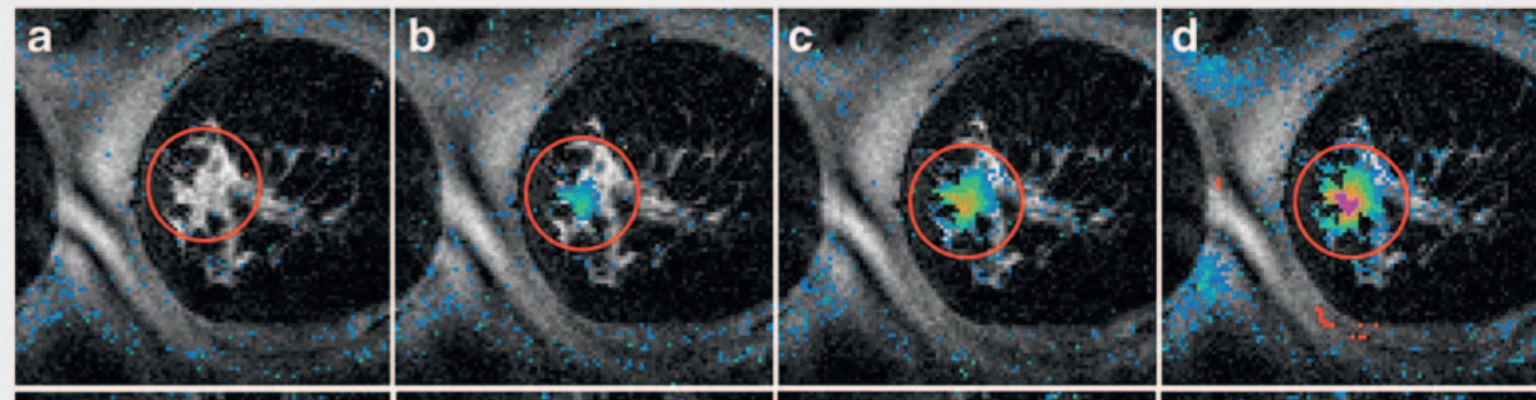

$\mathrm{T}\left[{ }^{\circ} \mathrm{C}\right]$
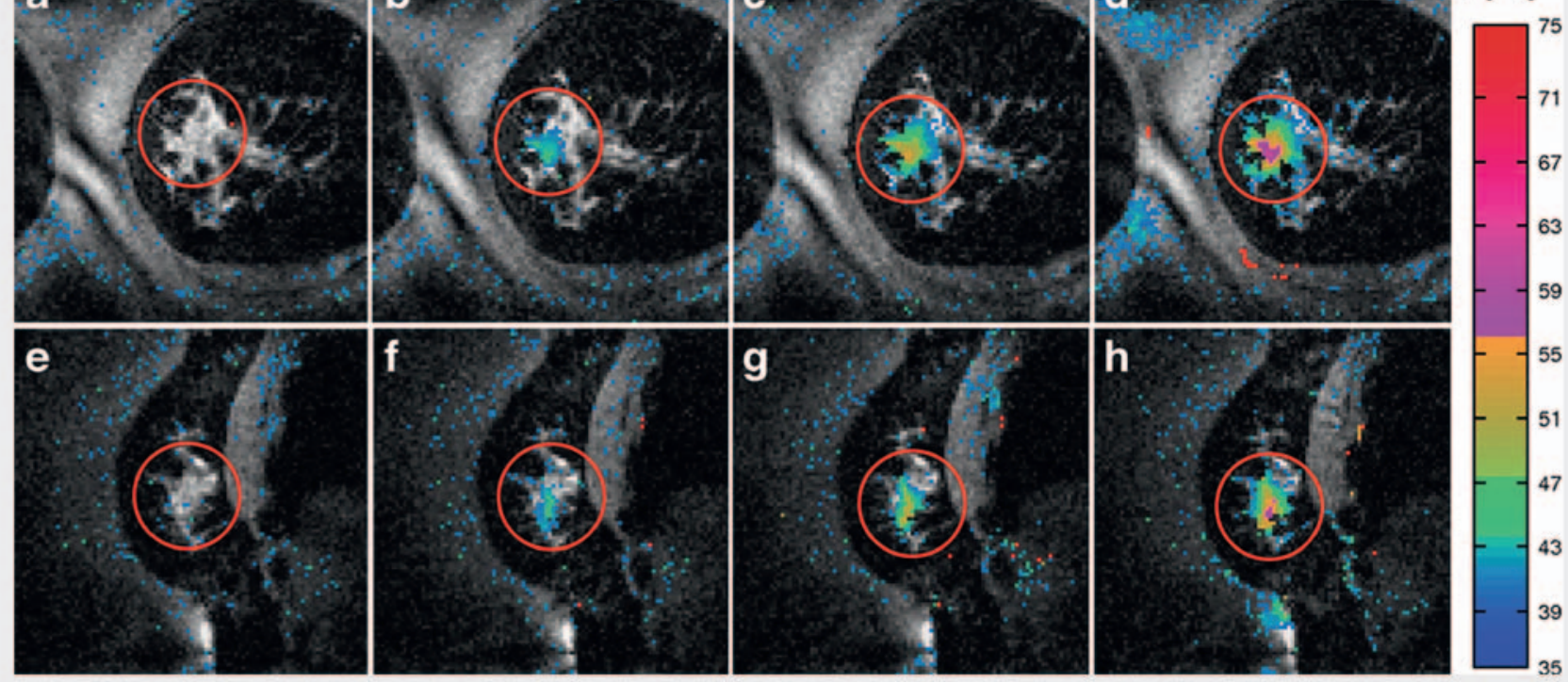

- Fig. 3 MR thermometry data obtained during breast sonication (prototype, Profound Medical, Mississauga, Canada) overlaid on anatomical coronal a - d and sagittal e- $\mathbf{h}$ images. Source: Merckel LG, Knuttel FM, Deckers R, van Dalen T, Schubert G, Peters NH, Weits T, van Diest PJ, Mali WP, Vaessen PH, van Gorp JM, Moonen CT, Bartels LW, van den Bosch MA. First clinical experience with a dedicated MRI-guided high-intensity focused ultrasound system for breast cancer ablation. Eur Radiol 2016; 26: 4037 - 4046 [rerif].

- Abb. 3 MR-Thermometrie-Daten aufgezeichnet während der Brusttherapie (prototype, Profound Medical, Mississauga, Canada), die anatomische koronare $\mathbf{a}-\mathbf{d}$ und sagittale $\mathbf{e}-\mathbf{h}$ Bilder überlagern. Quelle: Merckel LG, Knuttel FM, Deckers R et al. First clinical experience with a dedicated MRIguided high-intensity focused ultrasound system for breast cancer ablation. Eur Radiol 2016; 26: 4037 - 4046 [rerif]. 

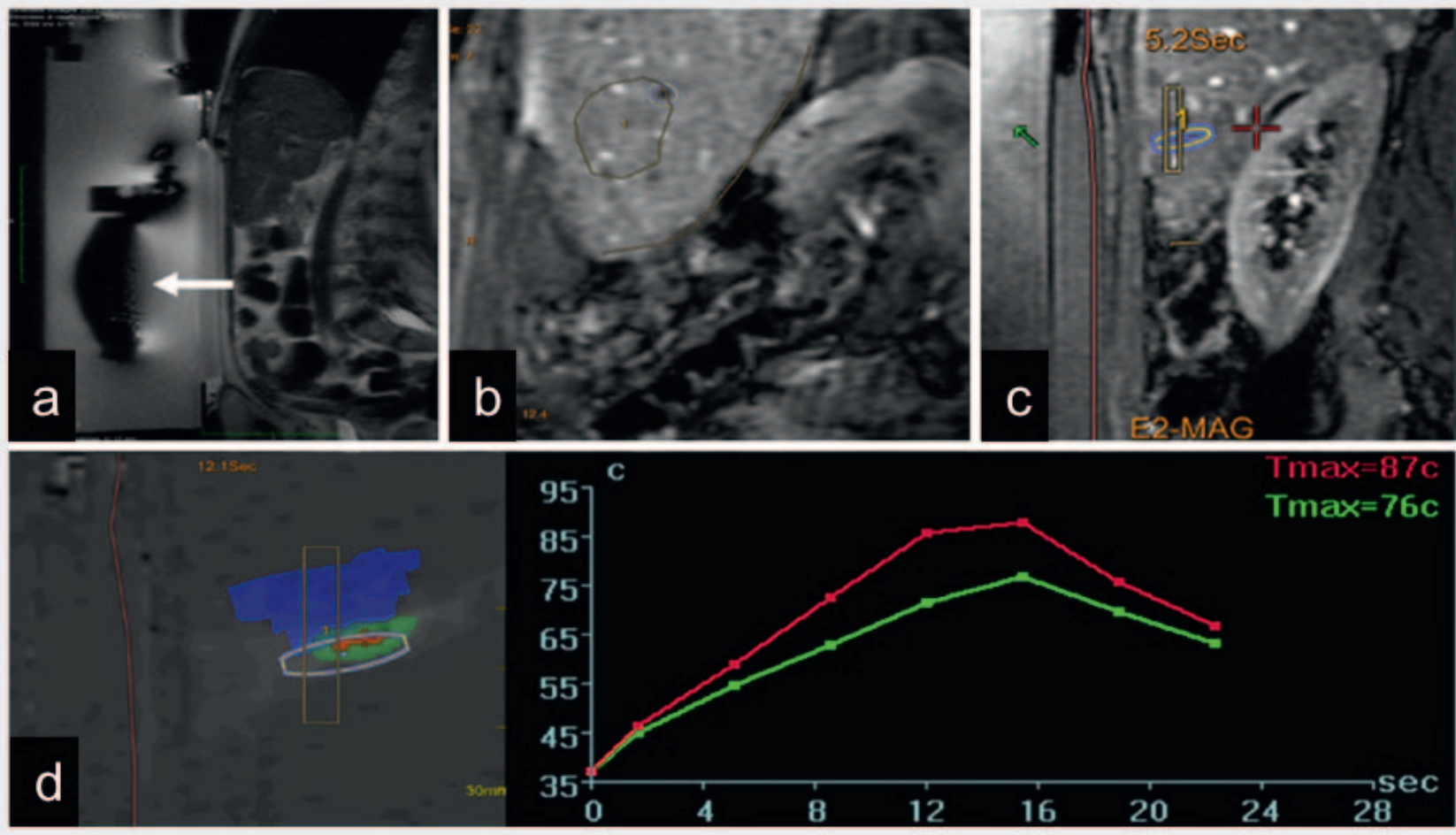

\begin{abstract}
- Fig. 4 MR-HIFU treatment of a subcapsular hepatocellular carcinoma (ExAblate 2100, InSightec, Haifa, Israel). a Patient in prone position on the MR-HIFU patient bed. The arrow points out the position of the transducer. $\mathbf{b}$ Manual delineation of the target tissue, $\mathbf{c}$ skin: red line, sonication area: yellow box. $\mathbf{d}$ Temperature maps and profiles acquired with PRFS MR thermometry. Source: Anzidei M, Napoli A, Sandolo F, Marincola BC, Di Martino M, Berloco P, Bosco S, Bezzi M, Catalano C. Magnetic resonance-guided focused ultrasound ablation in abdominal moving organs: a feasibility study in selected cases of pancreatic and liver cancer. Cardiovasc Intervent Radiol 2014; 37: 1611 - 1617 [rerif].

- Abb. 4 MR-HIFU-Therapie eines subkapsulär gelegenen hepatozellulären Karzinoms (ExAblate 2100, InSightec, Haifa, Israel). a Der Patient liegt in Bauchlage auf dem MR-Tisch, der Pfeil zeigt auf den Transducer. b Manuelle Markierung des Zielgewebes. c Haut: rote Linie, Sonikations-Zone: gelbe Box. d Temperaturkarten und -profile, die mittels PRFS-MR-Thermometrie gemessen wurden. Quelle: Anzidei M, Napoli A, Sandolo F et al. Magnetic resonance-guided focused ultrasound ablation in abdominal moving organs: a feasibility study in selected cases of pancreatic and liver cancer. Cardiovasc Intervent Radiol 2014; 37: 1611 - 1617 [rerif].
\end{abstract}

outcome. In a further prospective phase I clinical trial using the MRI-guided ExAblate ${ }^{\circledR}$ transrectal HIFU probe, 14 men with lowvolume low-grade prostate cancer (Gleason 6) underwent treatment with 12 men completing a 2-year follow-up [17]. The mean sonication time was 117 min with all patients tolerating the procedure well. One patient developed acute urinary retention after treatment, probably due to a urinary tract infection and another patient developed epididymo-orchitis, both complications resolved quickly under treatment with antibiotics. The median overall satisfaction at 6 months was high. At 24 months, sexual function was the only parameter to show a trend toward decline from baseline, however, not significantly. The median PSA decreased by $38.8 \%$ and remained low except in one patient who eventually underwent radiation therapy. After 6 and 24 months, none of the patients had positive multiparametric MR imaging findings. However, template biopsy at 24 months revealed 2 patients with residual tumor in the treated prostate tissue. Nevertheless, this study also demonstrated transrectal HIFU to be feasible with a favorable safety and functional profile, even though the sample size was small.
For the transurethral TULSA-PRO ${ }^{\circledR}$ system, an initial treat and resect study showed good agreement between the delineated tissue in the temperature maps acquired during treatment studies and the extent of necrotic tissue as found in histology. In this pilot study, five men with localized prostate cancer on multiparametric MRI were treated by focal MR-HIFU prior to radical prostatectomy [18]. After prostatectomy, whole mount histological sections demonstrated successful focal MR-HIFU treatment with target volumes of $4-20 \mathrm{ml}$ within radii of up to $35 \mathrm{~mm}$ from the urethra with a mean spatial targeting accuracy of $1.5 \pm 2.8 \mathrm{~mm}$. The mean treatment accuracy with respect to histology was $0.4 \pm 1.7 \mathrm{~mm}$ with all index tumors being inside the histological outer limit of thermal injury and completely covered by the targeted focal HIFU ablation. In a subsequent prospective multinational phase I clinical trial, 30 men with low- and intermediate-risk prostate cancer (Gleason 6 or 7a) were treated using the MRI-guided TULSA-PRO ${ }^{\circledR}$ transurethral HIFU transducer and followed over one year [19]. The median treatment time was 36 min and 29 participants were successfully discharged already after 24 hours. Treatment-related adverse events included 

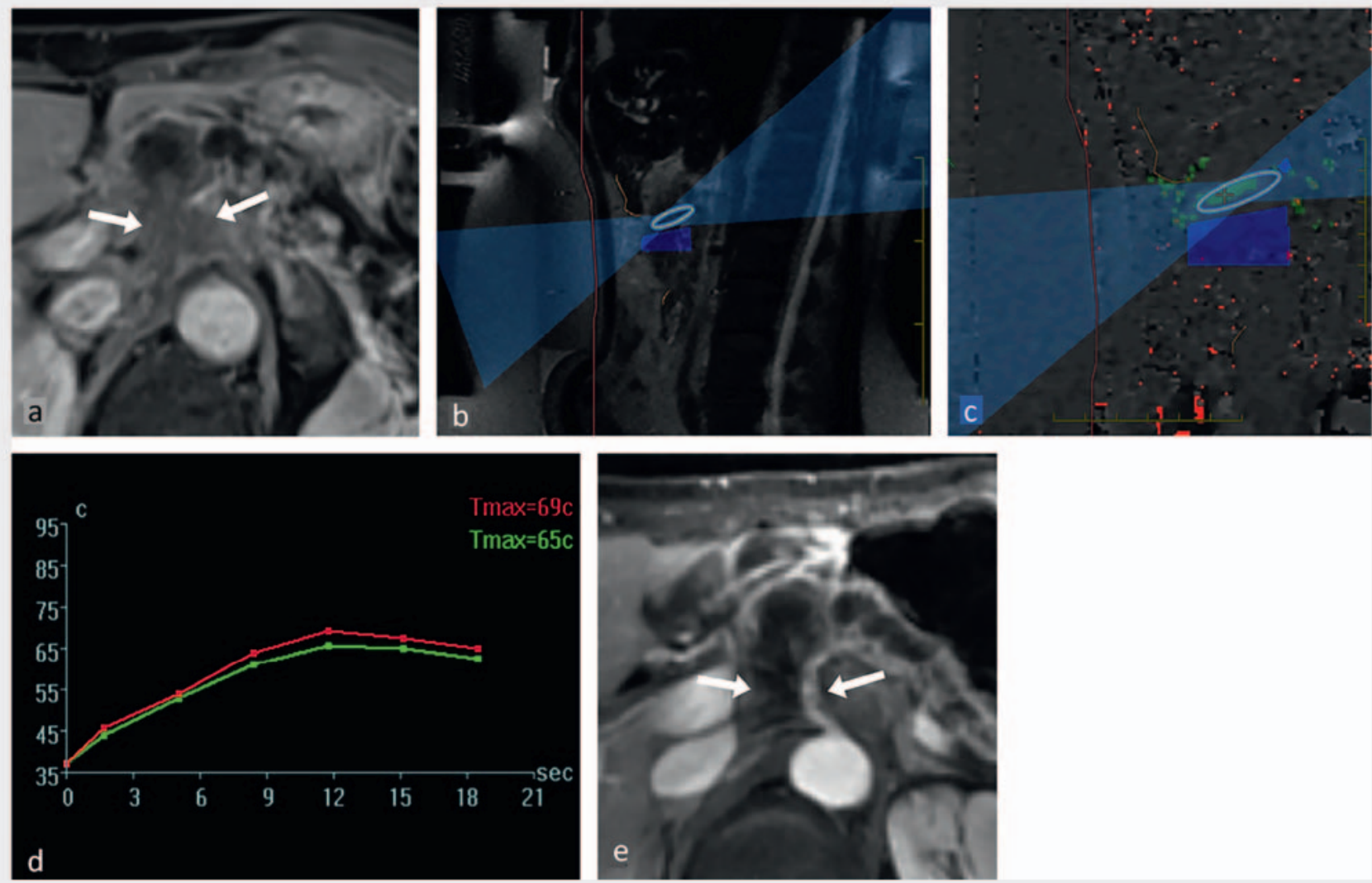

- Fig. 5 MR-HIFU treatment of a pancreatic tumor (ExAblate 2100, InSightec, Haifa, Israel). a Axial, contrast-enhanced MR image showing a pancreatic tumor within the pancreatic body determining the encasement of the celiac artery (arrows). b Planning of MR-HIFU sonication for a patient placed in prone position on the HIFU transducer c MR-thermometry map acquired during ablation. $\mathbf{d}$ Temperature profile within the focal spot over the time course of ablation, e contrast-enhanced MR image after treatment revealing the presence of non-perfused tissue corresponding to the ablated area within the tumor tissue. Source: Anzidei M, Marincola BC, Bezzi M, Brachetti G, Nudo F, Cortesi E, Berloco P, Catalano C, Napoli A. Magnetic resonance-guided high-intensity focused ultrasound treatment of locally advanced pancreatic adenocarcinoma: preliminary experience for pain palliation and local tumor control. Invest Radiol 2014; 49: 759 - 765 [rerif].

- Abb.5 MR-HIFU-Therapie eines Pankreastumors (ExAblate 2100, InSightec, Haifa, Israel). a Axiale, kontrastunterstützte MR-Bilder zeigen einen Pankreastumor im Pankreaskorpus mit Umscheidung des Truncus coeliacus (Pfeile). b Planung der MR-HIFU-Therapie für einen Patienten, der bäuchlings auf dem HIFU-Transducer liegt. c MR-Thermometrie-Daten, aufgezeichnet während der Ablation. d Temperaturprofil innerhalb des Fokuspunktes während der Ablation. e Kontrastunterstützte MR-Bilder nach Therapie mit Nachweis nicht perfundierten Gewebes analog zum abladierten Gewebe innerhalb des Tumors. Quelle: Anzidei M, Marincola BC, Bezzi M et al. Magnetic resonance-guided high-intensity focused ultrasound treatment of locally advanced pancreatic adenocarcinoma: preliminary experience for pain palliation and local tumor control. Invest Radiol 2014; 49: 759 - 765 [rerif].

urinary tract infections (33\%), acute urinary retention (27\%), and epididymitis (3\%). No intraoperative complications, rectal injuries, fistulas or severe post-therapeutic urinary incontinence was observed. After 1 year only one patient had low-grade urinary incontinence. The median pretreatment erectile function remained widely stable with 13 before treatment (IQR: $6-28$ ) compared to 13 (IQR: $5-25$ ) at the 12-month follow-up. The median PSA decreased by $87 \%$ at the 1 -month control and was stable at $0.8 \mathrm{ng} / \mathrm{ml}$ (IQR: $0.6-1.1)$ to 12 months. However, in this clinical safety and feasibility study with the therapeutic intent of conservative whole-gland ablation including a $3 \mathrm{~mm}$ safety margin towards the capsule, residual viable tumor was found in $55 \%$ of the patients at the 1 -year control.
Anyway, the available data for MR-guided HIFU are still very limited and have not yet been fully analyzed. In general, the majority of prostate cancers are situated in the posterior aspect of the peripheral zone near by the rectal wall and neurovascular bundle and some other less frequent tumors are located at the anterior fibromuscular stroma. In the comparison of both techniques, the theoretical advantage of the transurethral TULSA-PRO ${ }^{\circledR}$ approach is related to the fact that these lesions might be better ablated up to the prostate capsule with a lower risk of harming the rectum wall and neurovascular bundle in the far field and to be closer to the anterior stroma with fewer side effects in the near field [20]. Moreover, the transurethral approach allows for simultaneous placement of a rectal cooling device even further lowering the risk of rectal injuries and fistula. A disadvantage of the 
transurethral approach is the risk for urethral injuries during insertion of the catheter or during sonication, which, however, has been shown to be a rare complication. On the other hand, the transrectal ExAblate ${ }^{\circledR}$ system seems to be easier to place within the rectum and allows overtreatment outside the prostate capsule, e. g. in the case of extraprostatic infiltration. However, the safety margin towards the rectal wall in the direct near field of the transducer implicates the higher risk of residual tumor tissue at the most common PCa location at the posterior peripheral zone adjacent to the prostate capsule.

An exemplary workflow for prostate ablation using the TULSA$\mathrm{PRO}^{\circledR}$ is shown in > Fig. 1a-h.

Altogether, MR-HIFU seems to be a promising treatment option for clinically low- to intermediate-risk prostate cancer detected on MRI and for salvage ablation of radiation-recurrent PCa. Nevertheless, further studies are needed to compare the efficacy, local recurrence and risk of complications of both currently available MR-HIFU procedures for prostate cancer treatment.

It should be noted that the clinical use of MR-HIFU is accepted in the current S3-guideline for prostate cancer when performed under study conditions with the patient still needing active surveillance after treatment.

\section{Breast}

Early stage, localized breast cancer presents a potential application for minimally invasive and local ablative techniques such as radiofrequency, microwave, laser, cryo and HIFU techniques. The current clinical standard for low-stage invasive breast carcinomas is local resection in a breast-conserving manner with high cure rates and long-term survival of more than $90 \%$ [21]. Comparable to local resection, ablative techniques seem feasible as long as a safety margin of at least $10 \mathrm{~mm}$ is observed and other relevant criteria such as histology, hormone receptor status, assessment of sentinel lymph node and post-interventional therapy standards are met [22]. A challenge for all ablative techniques is to achieve total tumor ablation including a safety margin, while no post-interventional histological assessment of the tumor rim is available for confirmation. Clinical outcomes comparing the above-mentioned ablative techniques for the treatment of breast cancer were recently summarized and analyzed by Peek et al. [23]. Overall, few studies have been performed with low patient numbers, which makes a systematic comparison of all techniques with respect to outcome and side effects difficult. From the total 1627 patients included in the analysis, 227 patients were treated with MR-HIFU.

MR-HIFU treatment of breast fibroadenomas was first reported by Hynynen et al. [24], demonstrating 8 complete or partial ablations of a total of 11 treated lesions. Patients were placed on the HIFU system and sonicated from anterior, while a water bag provided acoustic coupling. Most clinical MR-HIFU studies to date have been performed with anterior sonication using the commercial MR-HIFU ExAblate ${ }^{\circledR}$ system (InSightec, Haifa, Israel) [25, 26]. In the case of anterior sonication, attention has to be paid to prevent structures in the far field from heating, such as the pectoral muscle, ribs, or lung tissue (tissue/air interface), all limiting possi- ble target locations, while near field heating led to skin burns in some cases. Clinical data showed that several tumors could not be entirely ablated, possibly due to the fact that not enough acoustic energy could be deposited due to the above-mentioned limitations or due to misplacement of the HIFU focus point [24]. Nevertheless, the outcome achieved with MR-HIFU was comparable to other ablation techniques, while the side effects were lower. A different approach is based on the lateral sonication of the tumor using dedicated large aperture breast HIFU transducers that have been developed with a different geometry ( $\triangleright$ Fig. 2a-d) [27-29]. Merckel et al. demonstrated partial ablation of breast cancer lesions in a treat and resect study with such a dedicated breast HIFU system (prototype, Profound Medical, Mississauga, Canada) [30]. Partial ablation was intended in order to compare treatment planning to temperature maps obtained during ablation and to ablated margins in overlay with histology sections. Results showed that lesion size correlated with applied overall acoustic energy although the achieved absolute temperatures differed per patients. Temperature feedback during ablation and calculation of thermal dose was complicated by poor temperature maps obtained by proton-resonance frequency shift (PRFS) thermometry for reasons such as breathing-induced motion and the presence of mostly fatty tissue ( $\triangleright$ Fig. $3 \mathbf{a}-\mathbf{h}$ ). Overall, MR-HIFU for the treatment of breast cancer can be considered a technically safe and patient-friendly method. However, before MR-HIFU could be considered as a treatment option for early stage and localized tumors, the technology needs to be further developed to guarantee complete tumor ablation including the necessary safety margin by improving image guidance and temperature mapping [31].

\section{Abdominal Applications}

US-HIFU has been used in several studies for the ablation of benign and malignant tumors in abdominal organs with good success rates, thus establishing an alternative to other minimally invasive thermal ablation methods for a selected group of patients. In general, treatments reveal partial or complete tumor ablation and are associated with comparably low side effects and complications [32 - 34]. However, especially for liver tumors, HIFU ablation has yet to be benchmarked against other minimally invasive procedures such as radiofrequency and microwave ablation, or transarterial chemoembolization in a multi-arm study which is currently not available.

For MR-HIFU, only a few case studies have been reported so far for the ablation of liver or pancreatic tumors [35]. MR-HIFU treatment of malignancies in abdominal organs, such as the liver, pancreas or kidney, is complicated by motion and often the acoustic beam path is obstructed by the thoracic cage or air-filled cavities in the bowel system. Respiratory motion, organ motion and bowel motion exacerbate focusing of the target tissue and the reliability of MR thermometry [36]. However, with new experimental approaches, respiratory excursion can be controlled by high-frequency jet ventilation [37] or apnea breaks for gated sonication [38]. Image guidance and navigator techniques allow tracking of organ movement to apply HIFU when the target is in a defined position or also to follow the movement 
of the target with the focus point [39-41]. Another technique currently under development is "beam-shaping" which excludes the ribs from the beam path thus protecting the patient from uncontrolled heating of the chest wall [42]. For the ablation of lesions in the liver dome, an iatrogenic intrapleural fluid infusion resulting in a pleural effusion could provide the necessary acoustic window [43]. While several studies using ultrasound-guided HIFU for the ablation of liver malignancies exist [44], only few case studies using MR-guided HIFU and demonstrating the feasibility of this approach have been published ( $\vee$ Fig. $4 a-e)$.

Ductal pancreatic cancer still has a particularly bad prognosis with a 2-year survival rate of less than $10 \%$. When diagnosed, $40 \%$ of these tumors have already metastasized, and in $60 \%$ of patients the tumor is locally inoperable due to infiltration of the portal vein, celiac trunk or superior mesenteric artery. In addition to radio-chemotherapy and a palliative operation, ablative procedures can help to control local tumor growth and reduce pain thereby improving the quality of life. So far, more than 1200 pancreatic cancer patients have been treated with US-HIFU, showing that this ablation method is safe with very few adverse events, provides pain palliation, and possibly extends life expectancy [33, 45-47]. A HIFU therapy of the pancreas is challenging because of air-filled bowel loops being present in the acoustic path. Thus, preparatory measures such as fasting, clyster or a nasogastric tube are important. Contact of the tumor with the duodenum or the bile duct can be a further contraindication for HIFU. While ultrasound guidance has the advantage that the acoustic beam path and possible obstructions by air pockets in the stomach or bowel can be directly probed, targeting of the pancreatic lesion is complicated due to the low intrinsic tissue contrast. Furthermore, heating to an ablative temperature is difficult to monitor as thermometry methods are lacking. Few case reports using MR-HIFU showed the feasibility of performing similar treatments under MR guidance [48]. For MR-HIFU therapy, patients are typically placed in a prone position on the system using, if necessary, an acoustically transparent dome-shaped gel pad or water-filled device to displace stomach and bowel that may potentially block the beam path. An example for MR-HIFU ablation of a pancreatic tumor is shown in $>$ Fig. 5a-e [48].

Similarly, ablation of renal cancer using US-HIFU has been sporadically performed indicating that ablation is possible in principle $[49,50]$.

\section{Conclusion}

Currently, the clinical use of MR-HIFU is restricted to thermal ablation of tissues and is clinically established for the treatment of uterine fibroids, pain alleviation of bone metastases and treatment of central tremor. Other promising applications in oncology either with curative intent or in a palliative setting are currently the subject of preclinical and clinical studies. One prominent and promising example is the treatment of prostate cancer using either a transrectal or transurethral probe, both of which recently received CE approval. As a noninvasive method, MR-HIFU treatments are patient-friendly with low complication rates and minor side effects and can be repeated if needed. Integration with MRI provides realtime spatial guidance, which further improves safety and therapeutic outcome. MRI-based temperature mapping offers the option for closed-loop temperature feedback for the delivery of well-defined thermal doses which allows protection of crucial structures from overheating while delivering a lethal thermal dose to the target tissue. While clinical pilot studies do exist for several new applications, prospective multi-arm clinical trials are urgently needed to demonstrate improved outcome compared to standard treatments.

\section{Conflict of Interest}

The authors declare that they have no conflict of interest.

References

[1] Kim EH, Andriole GL. Prostate-specific antigen-based screening: controversy and guidelines. BMC Med 2015; 13: 61

[2] Johansson JE, Adami HO, Andersson SO et al. High 10-year survival rate in patients with early, untreated prostatic cancer. JAMA 1992; 267: 2191-2196

[3] Chodak GW, Thisted RA, Gerber GS et al. Results of conservative management of clinically localized prostate cancer. N Engl J Med 1994; 330: $242-248$

[4] Wilt TJ, Brawer MK, Jones KM et al. Radical prostatectomy versus observation for localized prostate cancer. N Engl J Med 2012; 367: 203-213

[5] Bill-Axelson A, Holmberg L, Garmo $\mathrm{H}$ et al. Radical Prostatectomy or Watchful Waiting in Early Prostate Cancer. N Engl J Med 2014; 370: 932-942

[6] Klotz L, Zhang A, Lam R et al. Clinical results of long-term follow-up of a large, active surveillance cohort with localized prostate cancer. J Clin Oncol 2010; 28: 126-131

[7] Guillonneau B, el-Fettouh H, Baumert H et al. Laparoscopic radical prostatectomy: oncologic evaluation after 1000 cases at Montsouris Institute. J Urol 2003; 169: 1261-1266

[8] Han W, Partin AW, Chan DY et al. An evaluation of the decreasing incidence of positive surgical margins in a large retropubic prostatectomy series. J Urol 2004; 171: 23

[9] Cornford P, Bellmunt ], Bolla M et al. EAU-ESTRO-SIOG Guidelines on Prostate Cancer. Part II: Treatment of Relapsing, Metastatic, and Castration-Resistant Prostate Cancer. Eur Urol 2017; 71: 630-642

[10] McNeal JE. Cancer volume and site of origin of adenocarcinoma in the prostate: relationship to local and distant spread. Hum Pathol 1992; 23: $258-266$

[11] Rischmann P, Gelet A, Riche B et al. Focal High Intensity Focused Ultrasound of Unilateral Localized Prostate Cancer: A Prospective Multicentric Hemiablation Study of 111 Patients. Eur Urol 2017; 71: 267-273

[12] Chaussy CG, Thüroff S. High-Intensity Focused Ultrasound for the Treatment of Prostate Cancer: A Review. J Endourol 2017; 31: S30 - S37

[13] Rouvière $\mathrm{O}$, Gelet $\mathrm{A}$, Crouzet $\mathrm{S}$ et al. Prostate focused ultrasound focal therapy-imaging for the future. Nat Rev Clin Oncol 2012; 9: 721-727

[14] Napoli A, Anzidei M, De Nunzio C et al. Real-time Magnetic Resonanceguided High-intensity Focused Ultrasound Focal Therapy for Localised Prostate Cancer: Preliminary Experience. Eur Urol 2013; 63: 395 - 398

[15] Rouvière O, Souchon R, Salomir R et al. Transrectal high-intensity focused ultrasound ablation of prostate cancer: effective treatment requiring accurate imaging. Eur J Radiol 2007; 63: 317-327

[16] Ghai S, Perlis N, Lindner U et al. Magnetic resonance guided focused high frequency ultrasound ablation for focal therapy in prostate cancer phase 1 trial. Eur Radiol 2018; 28: 4281-4287 
[17] Kay KJ, Cheng CWS, Lau WKO et al. Focal Therapy for Prostate Cancer with In-Bore MR-guided Focused Ultrasound: Two-Year Follow-up of a Phase I Trial-Complications and Functional Outcomes. Radiology 2017; 285: 620-628

[18] Ramsay R, Mougenot C, Staruch R et al. Evaluation of Focal Ablation of Magnetic Resonance Imaging Defined Prostate Cancer Using Magnetic Resonance Imaging Controlled Transurethral Ultrasound Therapy with Prostatectomy as the Reference Standard. J Urol 2017; 197: 255-261

[19] Chin JL, Billia M, Relle J et al. Magnetic Resonance Imaging-Guided Transurethral Ultrasound Ablation of Prostate Tissue in Patients with Localized Prostate Cancer: A Prospective Phase 1 Clinical Trial. Eur Urol 2016; 70: 447-455

[20] Chopra R, Colquhoun A, Burtnyk M et al. MR Imaging-controlled Transurethral Ultrasound Therapy for Conformal Treatment of Prostate Tissue: Initial Feasibility in Humans. Radiology 2012; 265: 303-313

[21] Jeon YW, Choi JE, Heung KP et al. Impact of local surgical treatment on survival in young women with $\mathrm{T} 1$ breast cancer: long-term results of a population-based cohort. Breast Cancer Res Treat 2013; 138: 475-484

[22] Merckel LG, Bartels LW, Köhler MO et al. MR-guided high-intensity focused ultrasound ablation of breast cancer with a dedicated breast platform. Cardiovasc Intervent Radiol 2013; 36: 292-301

[23] Peek MC, Ahmed M, Napoli A et al. Minimally invasive ablative techniques in the treatment of breast cancer: a systematic review and meta-analysis. Int J Hyperthermia 2016; 33: 1-12

[24] Hynynen K, Pomeroy O, Smith DN et al. MR imaging-guided focused ultrasound surgery of fibroadenomas in the breast: a feasibility study. Radiology 2001; 219: 176-185

[25] Zippel DB, Papa MZ. The use of MR imaging guided focused ultrasound in breast cancer patients: a preliminary phase one study and review. Breast Cancer 2005; 12: 32-38

[26] Furusawa $\mathrm{H}$, Namba K, Najahara $\mathrm{H}$ et al. The evolving non-surgical ablation of breast cancer: MR guided focused ultrasound (MRgFUS). Breast Cancer 2007; 14: 55- 58

[27] Huber PE, Jenne JW, Rastert R et al. A new noninvasive approach in breast cancer therapy using magnetic resonance imaging-guided focused ultrasound surgery. Cancer Res 2001; 61: 8441-8447

[28] Payne A, Merrill R, Minalga E et al. Design and characterization of a laterally mounted phased-array transducer breast-specific MRgHIFU device with integrated 11-channel receiver array. Med Phys 2012; 39: 1552 - 1560

[29] Mougenot C, Tillander M, Koskela J et al. High intensity focused ultrasound with large aperture transducers: A MRI based focal point correction for tissue heterogeneity. Med Phys 2012; 39: 1936-1945

[30] Merckel LG, Knuttel FM, Deckers R et al. First clinical experience with a dedicated MRI-guided high-intensity focused ultrasound system for breast cancer ablation. Eur Radiol 2016; 26: 4037-4046

[31] Knuttel FM, van den Bosch MA. Magnetic Resonance-Guided High Intensity Focused Ultrasound Ablation of Breast Cancer. Adv Exp Med Biol 2016; 880: 65-81

[32] Diana M, Schiraldi L, Liu YY et al. High intensity focused ultrasound (HIFU) applied to hepato-bilio-pancreatic and the digestive systemcurrent state of the art and future perspectives. Hepatobiliary Surg Nutr 2016; 5: 329-344

[33] Dababou S, Marrocchio C, Rosenberg J et al. A meta-analysis of palliative treatment of pancreatic cancer with high intensity focused ultrasound. J Ther Ultrasound 2017; 5: 9
[34] Illing R, Kennedy J, Wu F et al. The safety and feasibility of extracorporeal high-intensity focused ultrasound (HIFU) for the treatment of liver and kidney tumors in a Western population. Br J Cancer 2005; 93: 890 - 895

[35] Anzidei M, Napoli A, Sandolo F et al. Magnetic resonance-guided focused ultrasound ablation in abdominal moving organs: a feasibility study in selected cases of pancreatic and liver cancer. Cardiovasc Intervent Radiol 2014; 37: $1611-1617$

[36] Zachiu C, Denis de Senneville B, Dmietriev ID et al. A framework for continuous target tracking during MR-guided high intensity focused ultrasound thermal ablations in the abdomen. J Ther Ultrasound 2017; 5: 27

[37] Courbon C, Bize P, Chollet RivierM et al. High-Frequency Jet Ventilation for HIFU. Cardiovasc Intervent Radiol 2014; 37: 1397 - 1398

[38] van Breugel JM, Wijlemans JW, Vaessen $\mathrm{HH}$ et al. Procedural sedation and analgesia for respiratory-gated MR-HIFU in the liver: a feasibility study. J Ther Ultrasound 2016; 4: 19

[39] Marquet F, Aubry JF, Pernot M et al. Optimal transcostal high-intensity focused ultrasound with combined real-time 3D movement tracking and correction. Phys Med Biol 2011; 56: 7061 - 7080

[40] Celicanin Z, Auboiroux V, Bieri O et al. Real-time method for motioncompensated MR thermometry and MRgHIFU treatment in abdominal organs. Magn Reson Med 2014; 72: 1087-1095

[41] Möri N, Jud C, Salomir R et al. Leveraging respiratory organ motion for non-invasive tumor treatment devices: a feasibility study. Phys Med Biol 2016; 61: $4247-4267$

[42] de Greef M, Schubert G, Wijlemans JW et al. Intercostal high intensity focused ultrasound for liver ablation: The influence of beam shaping on sonication efficacy and near-field risks. Med Phys 2015; 42: 4685-4697

[43] Wijlemans JW, de Greef M, Schubert G et al. Intrapleural Fluid Infusion for MR-Guided High-Intensity Focused Ultrasound Ablation in the Liver Dome. Acad Radiol 2014; 21: 1597-1602

[44] Orsi F, Varano G. Minimal invasive treatments for liver malignancies. Ultrason Sonochem 2015; 27: 659-667

[45] Vidal-Jove J, Perich E, del CastilloMA. Ultrasound Guided High Intensity Focused Ultrasound for malignant tumors: The Spanish experience of survival advantage in stage III and IV pancreatic cancer. Ultrason Sonochem 2015; 27: 703 -706

[46] Marinova M, Rauch M, Mücke M et al. High-intensity focused ultrasound (HIFU) for pancreatic carcinoma: evaluation of feasibility, reduction of tumour volume and pain intensity. Eur Radiol 2016; 26: 4047-4056

[47] Strunk HM, Henseler J, Rauch M et al. Clinical Use of High-Intensity Focused Ultrasound (HIFU) for Tumor and Pain Reduction in Advanced Pancreatic Cancer. Fortschr Röntgenstr 2016; 188: 662 - 670

[48] Anzidei M, Marincola BC, Bezzi M et al. Magnetic resonance-guided highintensity focused ultrasound treatment of locally advanced pancreatic adenocarcinoma: preliminary experience for pain palliation and local tumor control. Invest Radiol 2014; 49: 759-765

[49] Ritchie RW, Leslie T, Phillips R et al. Extracorporeal high intensity focused ultrasound for renal tumours: a 3-year follow-up. BJU Int 2010; 106: 1004-1009

[50] Wu F, Wang ZB, Chen WZ et al. Preliminary experience using high intensity focused ultrasound for the treatment of patients with advanced stage renal malignancy. J Urol 2003; 170: 2237-2240 